\title{
Strategy of selection of new cultivars of tomato for the South of Ukraine
}

\author{
V. Lymar, \\ Candidate of Agricultural Sciences \\ O. Kholodniak \\ South State Agricultural Experimental Station IWPaM NAAS
}

The purpose. To develop the strategy of selection of productive with choice quality of fruits heatresistant genotypes of tomato adapted for growing in conditions of steppe zone of Ukraine. Methods. Laboratory, field, statistical. Results. Physical-mechanical properties of fruit of a tomato are closely related with resistivity against compression failure $(r=0,61)$, content of dry soluble substance $(r=0,62)$ and ratio of soluble substance to insoluble $(r=-0,57)$. Consumer features are related with mass of fruit $(r=0,52)$, ratio of soluble substance in insoluble $(r=0,69)$, and content of Acidum ascorbinicum $(r=0,67)$. During selection for rising productivity and heat resistance depression of quality of fruit $(r=-0,45)$ is possible. Conclusions. In new cultivars of tomato it is possible to attain the desirable compromise between heat resistance, productivity and quality of fruits.

Key words: tomato, clusters, factors, correlations.

Formulation of the problem. The temperature of the air increased on $0,74{ }^{\circ} \mathrm{C}$ for 100 years in the world. This index in two times higher in Ukraine. The most stressful conditions for the development of vegetable production are observed in the south of Ukraine - Mykolaiv and Kherson regions. [7]

The level of implementation of the genetic potential of crops in this condition ranging from 25 to $35 \%$ at the last decade. [2] Ministry of Agrarian Policy and Food of Ukraine and the National Academy of Agrarian Sciences of Ukraine are working out priority directions of innovative development of agrarian sector, main of which is breeding of modern, highly productive varieties and hybrids of agricultural crops, adapted to the climatic changes, able to reveal their potential to $70-75 \%$ in appropriate farming practices. [6]

But, the breeders have some difficulties - negative correlation between potential productivity and resistance to environmental stress of varieties and hybrids [1].

Therefore, the breeding of productive heat-resistant genotypes of tomato with high-quality fruit, adapted to growing conditions in the steppe zone of Ukraine is a very actual problem.

Analysis of recent research and publications on the subject. The development of strategies tomato breeding for specific production conditions - is an essential step of the new genotypes creation. Depending on the aim, the relationship between the components of yield $[16,18]$, resistance to abiotic environmental factors [13], the chemical composition of the fruit [15] are investigated. Methods of component $[17,19]$ and cluster analysis [14] are widely used for it.

The purpose of research. To develop a breeding strategy of heat-resistant tomato genotypes with high fruit quality, adapted to growing conditions in the steppe zone of Ukraine.

Materials and methods of research. Studies were conducted on 30 samples of tomato in open ground, at the site of a drip irrigation, located in SE EF "Velikiy Klin " (46 ${ }^{\circ} 19^{\prime} 46.1$ "N $\left.32^{\circ} 35^{\prime} 51.2^{\prime \prime} \mathrm{E}\right)$, South State Agricultural Experimental Station IWPaM NAAS in 2006-2015 years according to [3]. Farming equipment in the experiments meets the DSTU 6008: 2008. Harvesting - manually, by weight [8]. Samples were taken for chemical analysis of fruit. [9] The analysis was performed according [10, 11, 12]. Assessment of collection samples for heat resistance were performed [4]. Statistical analysis of the results of research carried out by [5].

Results. In the evaluation of 30 collected samples for 12 traits, it was found, that the greater variability (CV) for the observed traits was the ratio of soluble to insoluble dry matter $(C V=60,03)$, sugar-acid index $(C V=29,67)$ and heat resistance $(C V=27.85)$. (Fig. 1.) Thus, these three traits, the likelihood of breeding efficiency much higher than others. Reducing the fate of insoluble dry matter in the fruit of the tomato can receive more concentrated tomato paste during processing. Sugar-acid index affects the taste of fresh tomato fruit and tomato product quality and duration of storage. The heat resistance of tomato plants enables stable yield during high daytime temperatures. 
Analysis of graphic matrix of paired correlations (Fig. 2) between the 12 studied traits showed the need for multivariate factor analysis to determine the independent complex characteristics that would define the most important features of the object.

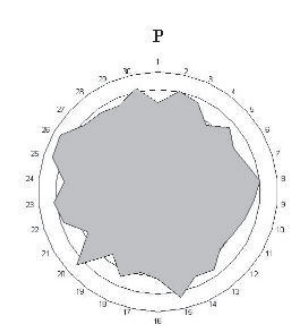

HR

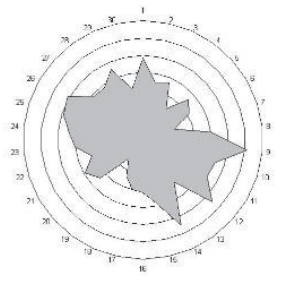

AS

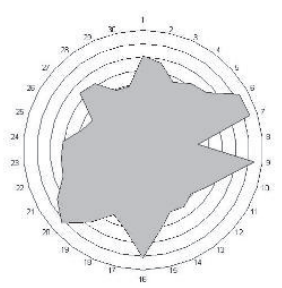

MF

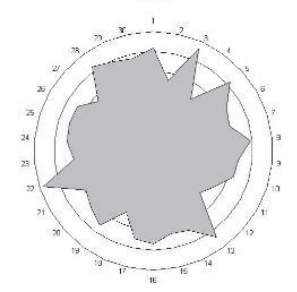

DM

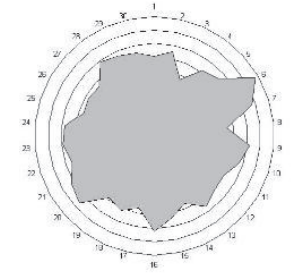

TA

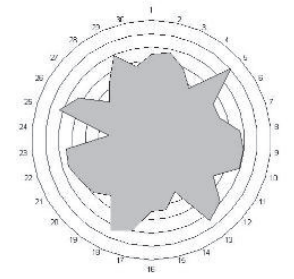

EL

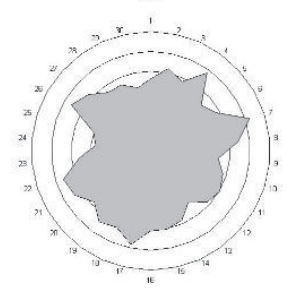

SS

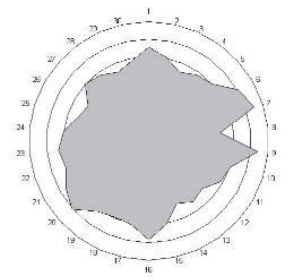

SAI

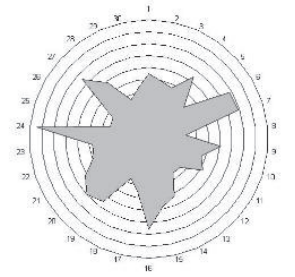

$\mathrm{RC}$

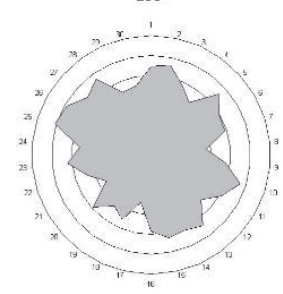

SSIDM

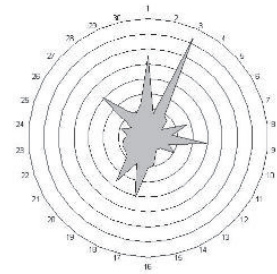

AA

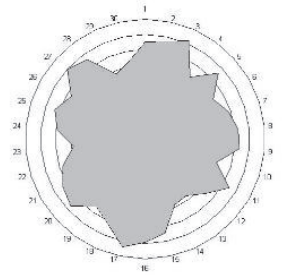

Fig. 1.12 traits of collection tomato samples, $n=30$ (2007-2010): $P$ - productivity, $\mathrm{kg} / \mathrm{m} 2, \mathrm{MF}$ - weight of the fruit, $\mathrm{g}, E L$ - efforts to break, $\mathrm{kg}, R C$ - resistance to crushing, $\mathrm{g} / \mathrm{g}, \mathrm{HR}$ - heat resistance,\%, DM - dry matter, \%, SS - soluble dry matter, \%, SS/DM - the ratio of soluble dry matter to insoluble, AS - the amount of sugars, \%, TA - volumetric acid , SAl - sugar-acid index, AA - ascorbic acid, $\mathrm{mg} / \%$.

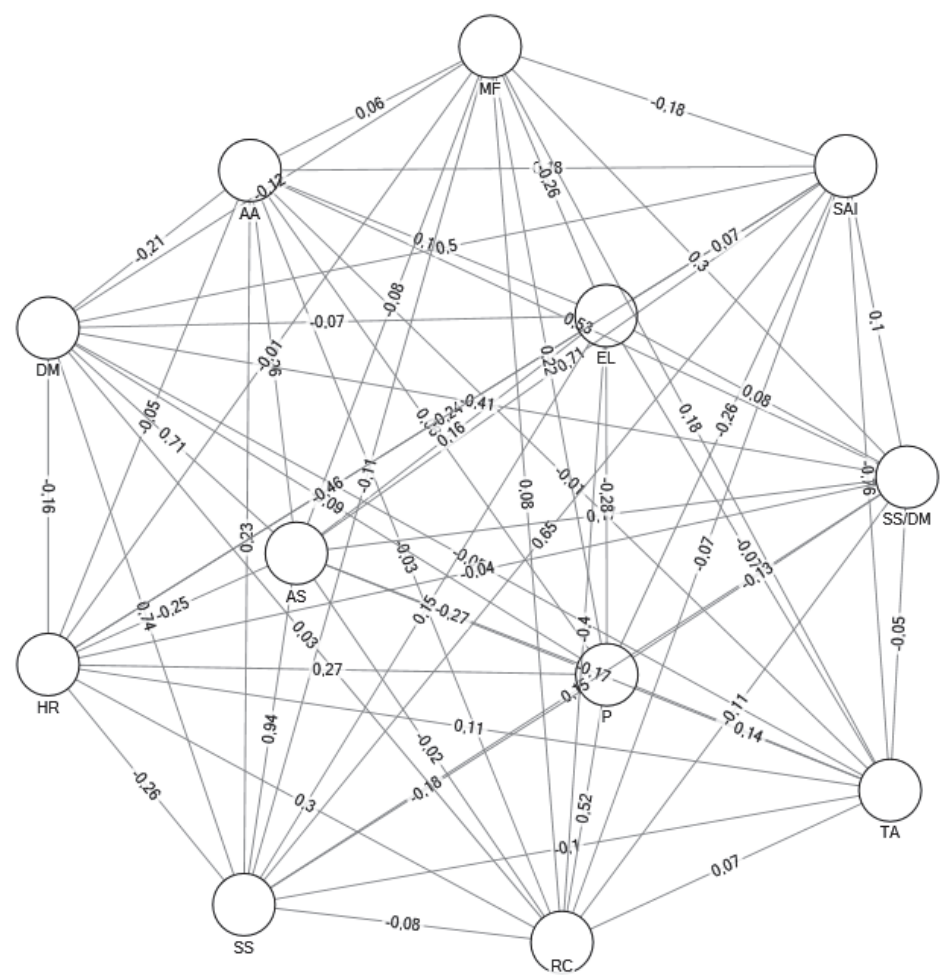

Fig. 2. Paired correlation between traits of collection samples of tomato (2007-2010) ( Fryuhtermana Rheingold Power location algorithm). 
Factor analysis conducted by principal component analysis showed, that the studied traits shared between four main components (PC), which cover $73 \%$ of the total variance. (Table 1)

Table 1 - Results of factor analysis by principal components

\begin{tabular}{|c|c|c|c|c|}
\hline Trait & PC 1 & PC 2 & PC 3 & PC 4 \\
\hline P & $-0,45$ & 0,43 & 0,38 & 0,01 \\
\hline MF & $-0,25$ & $-0,03$ & $\mathbf{0 , 5 2}$ & $-0,26$ \\
\hline EL & 0,33 & $\mathbf{- 0 , 6 0}$ & $-0,31$ & $-0,16$ \\
\hline RC & $-0,28$ & $\mathbf{0 , 6 1}$ & 0,38 & 0,12 \\
\hline HR & $-0,45$ & 0,37 & 0,23 & 0,25 \\
\hline DM & $\mathbf{0 , 6 7}$ & $\mathbf{0 , 6 2}$ & $-0,16$ & $-0,29$ \\
\hline SS & $\mathbf{0 , 8 7}$ & 0,21 & 0,23 & $-0,28$ \\
\hline SS/DM & 0,12 & $\mathbf{- 0 , 5 7}$ & $\mathbf{0 , 6 9}$ & 0,06 \\
\hline AS & $\mathbf{0 , 9 0}$ & 0,19 & 0,25 & $-0,21$ \\
\hline TA & $-0,44$ & 0,03 & 0,06 & $\mathbf{- 0 , 8 5}$ \\
\hline SAI & $\mathbf{0 , 8 5}$ & 0,14 & 0,11 & 0,46 \\
\hline AA & 0,21 & $-0,41$ & $\mathbf{0 , 6 7}$ & 0,01 \\
\hline The total variance & 3,65 & 2,05 & 1,79 & 1,32 \\
\hline Share in total variance & 0,30 & 0,17 & 0,15 & 0,11 \\
\hline
\end{tabular}

The first component (PC 1) indicates, that breeding for improved performance and heat resistance, may reduce the quality of the fruit $(r=(-0,45))$. That is, need only reach the required level of heat resistance, which allow not to lose the quality of the fruit. The second component (PC 2) indicates, that the physical and mechanical properties of the fruit closely related to resistance for crushing $(r=0,61)$, soluble dry matter content $(r=0,62)$ and the ratio of soluble to insoluble dry matter $(r=(-0,57))$. That is, during the selection, should seek a compromise between strength fruit (which depends largely on the fate of insoluble dry matter) and their quality (depending on the content of soluble dry matter). In addition, increased efforts to led the fruit from the stalk associated with a decrease in physical and mechanical properties of the fruit $(r=(-0,60))$, which is especially characteristic round form and flaps. The third component (PC 3) indicates that consumer characteristics are closely linked with fruit weight $(r=0,52)$, the ratio of soluble to insoluble dry matter $(r=0,69)$ and ascorbic acid content $(r=0,67)$. However, the suitability for mechanical harvesting limits fruit weight under 100 grams. The fourth component (PC 4) indicates, that a significant increase in the acidity of the fruit, will reduce the taste characteristics of products.

To establish the possibility of selection on traits, belonging to the first two principal components (PC 1, PC 2), which are key in this study, it was built correlation circle ( Fig. 3). 


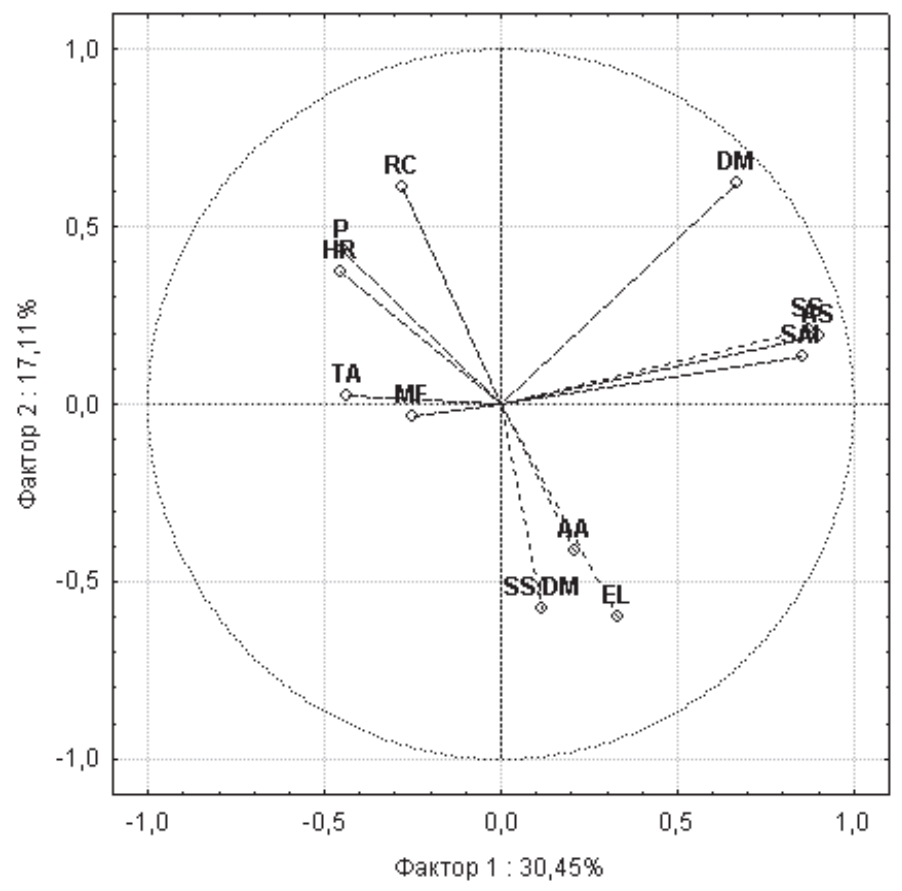

Fig. 3. Correlation circle ( axis of factors 1, 2)

This figure shows, that the traits, which are in opposite quarters of a circle, can be subjected to selection independently. That is, the selection process may achieve the desired compromise between heat resistance, sugar-acid index and the ratio of soluble to insoluble dry matter.

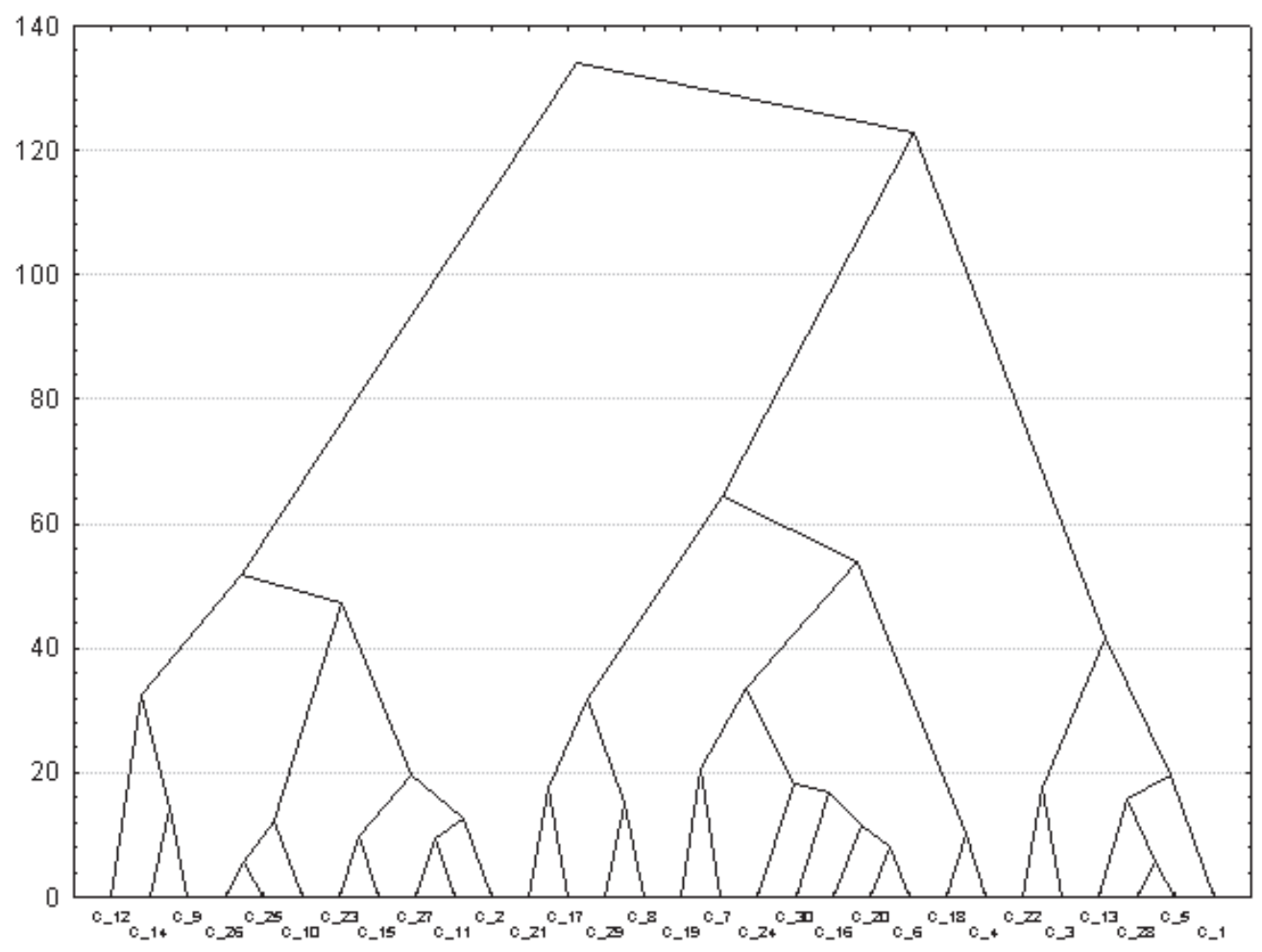

Fig. 4. The results of cluster analysis of collection samples of tomato for 12 traits (2007-2010):

C1 - Denarius, C2 - Rio Fuyeho , C3 - Moneymaker, C4 - French hrozdovyy , C5 - Asvon F1 (KS1140) , C6 - Slider , C7 - King market, C8 - Jessica, C9 - Malika F1, C10 - Carioca , C11 - Odeta , C12 M-1108, C13 - Corato , C14 - Success C15 - Missouri , C16 - H -2, C 17 - H -3, C 18 - Marathon , C19Ballad, C20 - Amulet, C21 - Carmen, C22 - Orion, C23 - Svyatoslav F1, C24 - Diablo F1, C25 - Rio Grande, C26 - Pilmek , C27 - Peto -86, C28 - Red Hunter, S29 - Warrior, C30 - Gentle, st. 
Table 2 - Characteristics of clusters.

\begin{tabular}{|c|c|c|c|c|c|c|c|}
\hline Trait & Cluster 1 & Cluster 2 & Cluster 3 & Trait & Cluster 1 & Cluster 2 & Cluster 3 \\
\hline P & 5,56 & 5,72 & 5,37 & SS & 5,21 & 4,84 & 4,93 \\
\hline MF & 76,00 & 94,56 & 96,89 & SS/DM & 3,88 & 4,49 & 5,88 \\
\hline EL & 2,02 & 1,80 & 2,07 & AS & 3,27 & 3,01 & 3,02 \\
\hline RC & 78,25 & 90,22 & 64,33 & TA & 0,28 & 0,33 & 0,31 \\
\hline HR & 35,28 & 45,87 & 33,26 & SAl & 12,28 & 9,21 & 10,01 \\
\hline DM & 6,72 & 6,31 & 6,17 & AA & 29,91 & 29,14 & 30,76 \\
\hline
\end{tabular}

Table 2 shows, that in the second cluster collected samples with the highest performance, heat resistance, resistance to crushing and minimal effort to lead a fruit from the stalk. In the first cluster arranged samples with the highest content of dry (soluble and general) matter and sugar-acid index. In the third - largest fruit weight and the ratio of soluble solids to solids. (Fig. 3)

According to all the findings, a model for future tomato varieties would be (table 3 ):

Table 3 - Model of new tomato varieties.

\begin{tabular}{|c|c|c|l|c|c|c|c|}
\hline traits & values & traits & values & traits & values & traits & values \\
\hline $\mathrm{P}$ & 5,72 & $\mathrm{RC}$ & 90,0 & $\mathrm{SS}$ & 5,21 & $\mathrm{TA}$ & $0,3-0,4$ \\
\hline $\mathrm{MF}$ & $76-100$ & $\mathrm{HR}$ & $35,0-45,0$ & $\mathrm{SS} / \mathrm{DM}$ & 7,0 & $\mathrm{SAI}$ & 12,28 \\
\hline $\mathrm{EL}$ & 1,80 & $\mathrm{DM}$ & 6,72 & $\mathrm{AS}$ & 3,27 & $\mathrm{AA}$ & 29,91 \\
\hline
\end{tabular}

Our researches set that for increase the possibilities of breeding in F2 as parental forms must select samples is the most distant clusters. (Table 4). And for rapid stabilization of breeding material necessary to use samples of the closest clusters or samples located along a single cluster.

Table 4 - Euclidean distance between clusters

\begin{tabular}{|l|c|c|}
\hline & Cluster 2 & Cluster 3 \\
\hline Cluster 1 & 2490,284 & $\mathbf{6 1 8 4 , 8 9 0}$ \\
\hline Cluster 2 & 0,000 & 882,752 \\
\hline
\end{tabular}

Devised this strategies, scientists of our Station in 2010-2015, were created and zoned new varieties of tomatoes Apollohet, Anaconda, Adele.

\section{Conclusions}

In the breeding process of new varieties of tomatoes only need to reach the required level of heat resistance, which allow not to lose the quality of the fruit. It is necessary to seek a compromise between strength fruit (which depends largely on the fate of insoluble dry matter) and their quality (depending on the content of soluble dry matter). In the process of selection of new genotypes may achieve the desired compromise between heat resistance, sugar-acid index and the ratio of soluble to insoluble dry matter.

To increase the possibilities of breeding in F2, as parental forms must select samples from the most distant clusters. For rapid stabilization of breeding material necessary to use samples of the closest clusters or samples, located along a single cluster.

\section{Bibliography}

1. Zhuchenko A.A. Strategiya adaptivnoy intensifikatsii selskogo hozyaystva (kontseptsiya)/A.A. Zhuchenko. - Puschino: ONTI PNTs RAN, 1994. - $148 \mathrm{~s}$.

2. Zubets M.V. Ekonomichni aspekti reformuvannya agrarno-promislovogo kompleksu Ukrayini/M.V. Zubets, M.D. Bezugliy. - K.: Agrarna nauka, 2010. - 32 s.

3. Kravchenko V.A. Metodika i tehnika selektsiynoyi roboti z tomatom/V.A. Kravchenko, O.V. Prilipka. -K. : Agrarna nauka, 2001. - $82 \mathrm{~s}$. 
4. Kravchenko V.A. Metodichnl rekomendatsiyi z viznachennya zharostiykosti zrazkiv ovochevih kultur (ogirok, pomidor, perets, baklazhan). Kravchenko V.A., Holodnyak O.G, Voevodin Yu.I. Naukovometodichne vidannya. - Herson: Aylant, 2010. - 4 s.

5. Litun P.P., Kirichenko V.V., Petrenkova V.P., Kolomatska V.P. Sistemniy analiz v selektsiyi polovih kultur, Harkiv 2009, $354 \mathrm{~s}$.

6. Pro shvalennya Kontseptsiyi rozvitku ovochivnitstva ta pererobnoyi galuzi: rozporyadzhennya kabinetu ministriv Ukrayini. Rozporyadzhennya vid 31 zhovtnya 2011 r. N 1120-r Kiyiv.

7. Tarariko O.G., Sirotenko O.V., Velichko V.A. Kosmichniy monitoring posushlivih yavisch//Visnik agrarnoyi nauki. 2012. \#10. S. 12-19.

8. DSTU 3246-95 Tomati svizhi. Tehnichni umovi. - [Vvedeniy $\mathrm{v}$ diyu 1997-01-01]. - K. :Derzhspozhivstandart, 1997. - 13.

9. DSTU ISO 874-2002 - Frukti ta ovochi svizhi. Vidbir prob (ISO 874:1980, IDT) - [Vvedeniy v diyu 2003-01-07]. - K. :Derzhspozhivstandart, 2003. - 15.

10. DSTU 4945:2008 Frukti, ovochi ta produkti yih pereroblennya. Piknometrichniy metod viznachennya vmistu rozchinnih suhih rechovin [Vvedeniy $v$ diyu 2009-01-01]. - K. :Derzhspozhivstandart, 2009. - 23.

11. DSTU 4954:2008 Produkti pereroblennya fruktiv ta ovochiv. Metodi viznachannya tsukriv [[Vvedeniy v diyu 2009-01-01]. - K. :Derzhspozhivstandart, 2009. - 23.

12. DSTU 4957:2008 Produkti pereroblennya fruktiv ta ovochiv. Metodi viznachennya titrovanoyi kislotnosti: [Vvedeniy v diyu 2009-01-01]. - K. :Derzhspozhivstandart, 2009. - 12.

13. Brdar-Jokanović M. Assessing Tomato Drought Tolerance Based on Selection Indices/M. BrdarJokanović, S. Pavlović, Z. Girek, M. Ugrinović, J. Zdravković//Ratar. Povrt. - 2014 - 51: 1 - p. 38-45.

14. Chernet $S$. Genetic diversity studies for quantitative traits of tomato (Solanum lycopersicon L.) genotypes in Western Tigray/S. Chernet, D. Belew, F. Abay//Northern Ethiopia, J. Plant Breed. Crop Sci. - 2014 - Vol. 6 (9) - p. 105-113.

15. Hernandez Suarez M. Chemical composition of tomato (Lycopersicon esculentum) from Tenerife/M. Hernandez Suarez, E.M. Rodrıguez Rodriguez, C. Diaz Romero//Canary Islands, Food Chemistry - 2008 - 106 - p. 1046-1056.

16. Islam B. M. R. Character association and path analysis of exotic tomato (Solanum lycopersicum L.) genotypes/B. M. R. Islam, N. A. Ivy, M. G. Rasul, M. Zakaria//Bangladesh J.PI. Breed. Genet. - 2010 23 (1) - p. 13-18.

17. Krasteva L. Principal component analysis of a canning determinate tomato collection in the IPGR, Sadovo/L. Krasteva, N. Velcheva, T. Mokreva//Bulgaria, Agroznanje - 2012 - vol. 13, br.1. - P.79-86.

18. Mehta N. Genetic Relationship of Growth and Development Traits with Fruit Yield in Tomato (Lycopersicon esculentum Mill)/N. Mehta, S. Asati, J. Karnataka//Agric. Sci. - 2008 -№ 21 (1) - p.92-96.

19. Mladenovic J. The biologically active (bioactive) compounds in tomato (Lycopersicon esculentum Mill.) As a function of genotype/J. Mladenovic, G. Acamovic - Đokovic, R. Pavlovic, M. Zdravkovic, Z. Girek, J. Zdravkovic//Bulgarian Journal of Agricultural Science - 2014 - 20 (No 4) - p. 877-882. 